\title{
Hyperthyroidism and vascular cell adhesion molecule- 1 are associated with a low ankle-brachial index
}

\begin{abstract}
Yu-Hsuan $\mathrm{Li}^{1,2} \& \mathrm{I}-\mathrm{Te} \mathrm{Lee}^{1,3,4,5 \bowtie}$
We aimed to assess the ankle-brachial index (ABI) in patients with Graves' disease. In the crosssectional assessments, 81 patients with drug-naïve Graves' disease and 235 with euthyroidism were enrolled. $A B I$ and vascular cell adhesion molecule-1 (VCAM-1) levels were assessed. In the prospective follow-up, 32 patients with Graves' disease were assessed again after antithyroid drugs for at least 4 weeks, and 32 age- and sex-matched controls with euthyroidism were also followed up. Patients with Graves' disease had a higher VCAM-1 level $(1309 \pm 292 \mathrm{vs.} 1009 \pm 168 \mathrm{ng} / \mathrm{mL}, \mathrm{P}<0.001)$ and a lower $A B I(0.98 \pm 0.11$ vs. $1.06 \pm 0.10, P<0.001)$ than those with euthyroidism. $A B I$ was significantly lower in patients with hyperthyroidism and a high VCAM-1 level than in those with euthyroidism and a low VCAM-1 level (regression coefficient: $-0.050,95 \%$ confidence interval $[\mathrm{Cl}]$ between -0.080 and -0.019; $P=0.001$ ). After treatment with antithyroid drugs, the change in free thyroxine (T4) level was inversely associated with the percentage change in $\mathrm{ABI}$ (regression coefficient: $-0.003,95 \% \mathrm{CI}$ between -0.005 and $-0.001, P=0.001$ ). A synergistic effect of VCAM-1 and free T4 on ABI reduction was observed. After a longitudinal follow-up, an increase in ABI was significantly correlated with a decrease in the free T4 level.
\end{abstract}

Thyroid dysfunction is one of the leading causes of endocrine disorders ${ }^{1-3}$. Graves' disease, characterized by autoimmune-associated hyperthyroidism, is the most common cause of excessive circulating thyroid hormone ${ }^{4,5}$. Thyroid hormones can directly act on cardiomyocytes and increase myocardial construction ${ }^{6}$. The risk of heart failure might increase as a result of changes in cardiac structure and hemodynamic regulation after long-term exposure to excessive thyroid hormone levels ${ }^{7,8}$.

Hyperthyroidism is associated with ischemic heart disease. Based on a Danish population-based cohort study, significantly increased risks of acute myocardial infarction and percutaneous coronary intervention were observed in patients after the diagnosis of hyperthyroidism ${ }^{9}$. Graves' disease was also reported to increase allcause mortality, cardiovascular (CV) mortality and CV events, including myocardial infarction, heart failure, ischemic stroke, and death ${ }^{10,11}$. Increased expression of vascular cell adhesion molecule-1 (VCAM-1) in endothelial cells has been reported in the thyroid gland of individuals with Graves' disease ${ }^{12}$. Excessive thyroid hormone levels are associated with systemic inflammation and endothelial dysfunction ${ }^{13,14}$.

Peripheral artery disease (PAD) in the lower extremities is a manifestation of atherosclerosis and is associated with CV mortality ${ }^{15,16}$. The ankle-brachial index (ABI) is a noninvasive tool to clinically screen for PAD and a lower ABI value is associated with higher CV mortality ${ }^{17-21}$. Since thyroid hormones have extensive effects on peripheral arteries and the mechanism might be associated with the overexpression of VCAM-1 in endothelial cells ${ }^{12,22-24}$, we hypothesized that high circulating levels of thyroid hormone and VCAM-1 would be associated with low ABI values in patients with Graves' disease.

\section{Materials and methods \\ Patients and procedures. This study was conducted in the Division of Endocrinology and Metabolism in Taichung Veterans General Hospital. Adults who visited our outpatient department due to a suspicion of thyroid} problems were screened between September 2012 and December 2017. The inclusion criteria for the case group

\footnotetext{
${ }^{1}$ Division of Endocrinology and Metabolism, Department of Internal Medicine, Taichung Veterans General Hospital, \#1650, Sec. 4, Taiwan Boulevard, Taichung 40705, Taiwan. ${ }^{2}$ Graduate Institute of Data Science, Taipei Medical University, Taipei 11031, Taiwan. ${ }^{3}$ School of Medicine, National Yang-Ming University, Taipei 11221, Taiwan. ${ }^{4}$ School of Medicine, Chung Shan Medical University, Taichung 40201, Taiwan. ${ }^{5}$ College of Science, Tunghai University, Taichung 40704, Taiwan. ${ }^{凶}$ email: itlee@vghtc.gov.tw
} 
were (1) a high serum free thyroxine (T4) level (>17.6 pg/mL), (2) a suppressed thyroid-stimulating hormone (TSH) level $(<0.4 \mu \mathrm{IU} / \mathrm{mL})$, (3) Graves' disease based on clinical manifestation, and (4) a TSH receptor antibody (TRAb) level $>1 \mathrm{U} / \mathrm{L}$; the inclusion criteria for the control group were (1) nodular goiter, (2) a normal serum free T4 level, and (3) a normal serum TSH level. The exclusion criteria for both the case group and control group were as follows: (1) a history of pharmacological treatment for thyroid diseases; (2) a history of diabetes mellitus; (3) a history of coronary artery disease; (4) a history of end-stage kidney disease; (5) a history of severe systemic disease, such as malignancies or psychiatric disorders; (6) current acute or chronic infectious diseases; (7) current thyrotoxic crisis; (8) current autoimmune diseases other than Graves' disease; and (9) current pregnancy. Based on the assessment at baseline, we also excluded patients who had (1) a fasting plasma glucose level $\geq 126 \mathrm{mg} / \mathrm{dL}$, (2) thyrotoxicosis other than Graves' disease, (3) an incomplete four-limb assessment of the ABI due to a known history of lower-extremity surgery or hemodialysis treatment, and (4) an ABI value $>1.40$. The study complied with the Declaration of Helsinki and was approved by the Institutional Review Board of Taichung Veterans General Hospital. Written consent was obtained from each patient before the study procedures were performed (Clinical Trial Registration Number: NCT02886949, ClinicalTrials.gov).

Procedure. This study included two parts of analytic assessments. For the case-control study at baseline, subjects underwent ABI assessments after an interview for the collection of medical information and anthropometric measurements. Blood samples were obtained for laboratory assessments after a fasting period $\geq 6 \mathrm{~h}$. Within a week after laboratory assessments, patients attended another visit and were categorized into Graves' disease and euthyroidism groups.

For the prospective observational study, 32 nonsmokers who started to use thionamide antithyroid drugs prescribed by the same research physician were consecutively invited in the case group for a follow-up assessment. We also followed up 32 age- and sex-matched nonsmokers in the control group. All of these invited subjects underwent anthropometric measurements, ABI assessments and blood sample collection after at least a 4-week period of follow-up.

Laboratory measurements. Plasma glucose levels were determined using the oxidase-peroxidase method (Wako Diagnostics, Tokyo, Japan). Serum creatinine and lipid levels were determined using commercial kits (Beckman Coulter, Fullerton, USA). Serum TSH (normal range 0.4-4 $\mu \mathrm{U} / \mathrm{mL}$ ) and free T4 (normal range 7.9-17.6 pg/mL) levels were determined using chemiluminescent immunoassays (Siemens Healthcare Diagnostics Inc., Llanberis, United Kingdom). TRAb levels were determined using the chemiluminescent method (normal level<1 U/L; Roche Diagnostics, Mannheim, Germany). Serum C-reactive protein (CRP) was determined using an ELISA kit (R\&D Systems, Minneapolis, MN, USA). The serum VCAM-1 concentration was determined by ELISA (R\&D Systems, Minneapolis, USA). The estimated glomerular filtration rate (eGFR) was calculated according to the Modification of Diet in Renal Disease equation ${ }^{25}$ as follows: $186 \times$ (serum creatinine $[\mathrm{mg} / \mathrm{dL}])^{-1.154} \times\left(\right.$ age $[\text { year] })^{-0.203}(\times 0.742$, if female $)$.

ABI assessment was performed in the supine position using the validated device (VP-1000 Plus; Omron Healthcare Co. Ltd., Kyoto, Japan) after patients rested for at least $5 \mathrm{~min}$. The lower systolic blood pressure of the two ankles was recorded as the ankle pressure. ABI values were calculated by dividing the recorded systolic pressure of the ankle by the higher systolic pressure of both arms ${ }^{17}$. The brachial-ankle pulse wave velocity (baPWV) was automatically determined using the ABI device. The reproducibility of the ABI was examined by repeated assessments in 20 subjects. A highly positive correlation of ABI values (correlation coefficient $[r]=0.937$, $\mathrm{P}<0.001$ ) was observed between the results of the first and second measurements. The $95 \%$ confidence interval (CI) was $0.004 \pm 0.050$ for the bias of the ABI between repeated measurements based on Bland-Altman plots.

Statistical analysis. We present the mean \pm the standard deviation (SD) for continuous variables and numbers with percentages (\%) for categorical data. The clinical variables were tested for statistically significant differences using Student's $t$ tests for continuous variables between two groups and using $\chi^{2}$ tests for categorical variables. The change in each continuous variable within a group at baseline and after follow-up was analyzed by paired $t$ tests. The association between ABI values and free T4 levels was determined using Pearson's correlation test. A two-tailed $\mathrm{P}$ value $<0.05$ was considered statistically significant. Statistical analysis was performed using SPSS 22.0 (IBM, Armonk, NY, USA).

\section{Results}

Case-control assessment. A total of 326 subjects were enrolled in this study. There were 81 subjects with Graves' disease in the case group and 235 subjects with euthyroidism in the control group (Fig. 1). The median TRAb level was 30.6 U/L (interquartile range between 5.8 and $57.1 \mathrm{U} / \mathrm{L}$ ) in the Graves' disease group. The characteristics of these two groups are shown in Table 1. Patients with Graves' disease had lower TSH and higher free T4 levels (both $\mathrm{P}$ values $<0.001$ ) because of different inclusion criteria from those with euthyroidism. Furthermore, the subjects with Graves' disease had a younger age $(\mathrm{P}<0.001)$; a higher proportion of current smokers $(\mathrm{P}<0.001)$; a lower body mass index $(\mathrm{BMI})(\mathrm{P}<0.001)$; a higher brachial systolic blood pressure $(\mathrm{P}=0.028)$; a higher heart rate $(\mathrm{P}<0.001)$; a higher glucose level $(\mathrm{P}=0.007)$; lower serum levels of total cholesterol $(\mathrm{P}<0.001)$, high-density lipoprotein $(\mathrm{HDL})$ cholesterol $(\mathrm{P}<0.001)$, and triglycerides $(\mathrm{P}=0.008)$; and a higher eGFR $(\mathrm{P}<0.001)$ than those with euthyroidism. Notably, subjects with Graves' disease had a lower systolic blood pressure at the ankle $(125 \pm 21$ vs. $131 \pm 22 \mathrm{mmHg}, \mathrm{P}=0.018)$ and a lower ABI value $(0.98 \pm 0.11$ vs. $1.06 \pm 0.10, \mathrm{P}<0.001)$. Subjects with Graves' disease also had a higher serum VCAM-1 level $(1309 \pm 292$ vs. $1009 \pm 168 \mathrm{ng} / \mathrm{mL}, \mathrm{P}<0.001)$. 


\section{Enrollment}

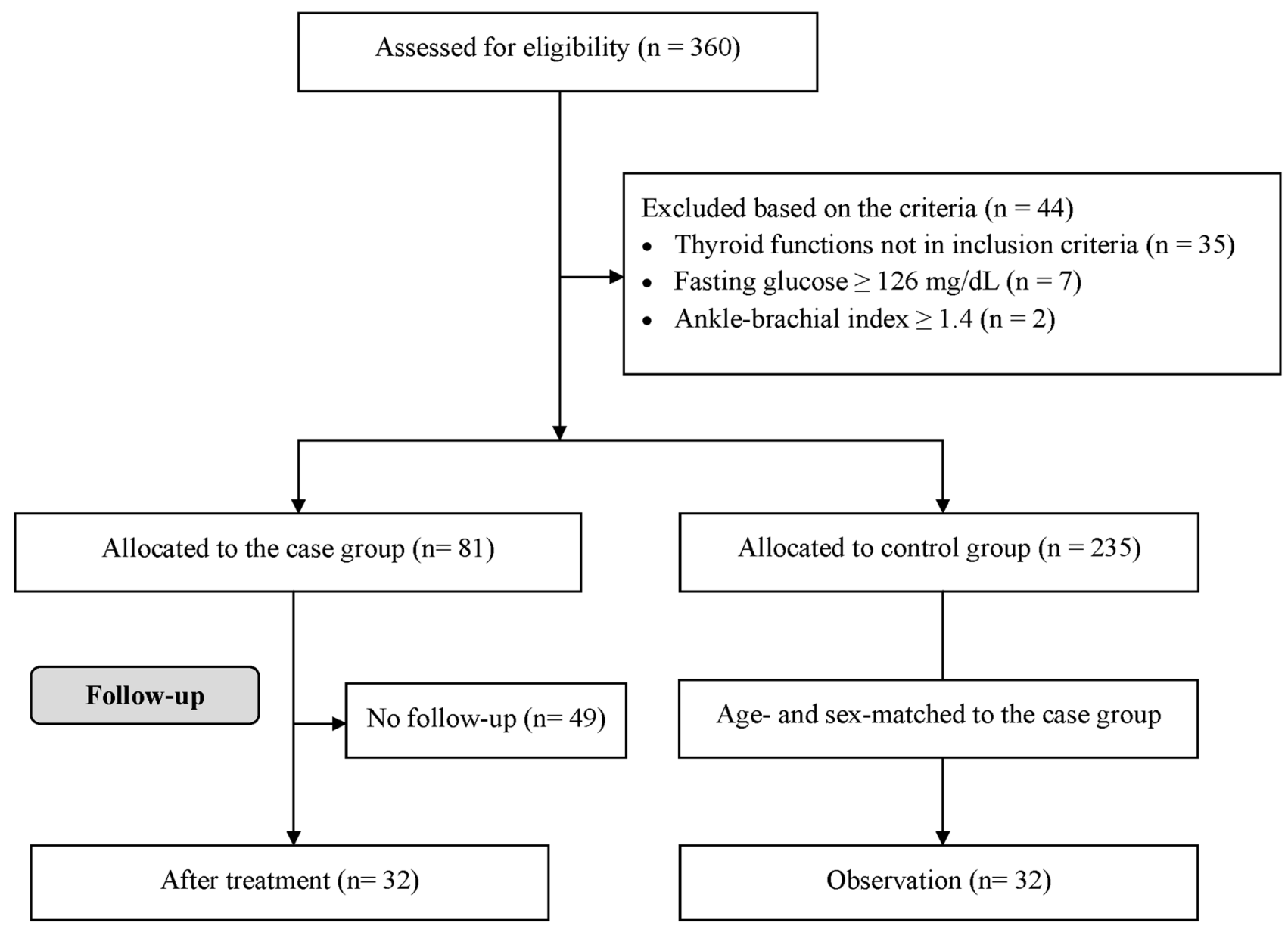

Figure 1. Flow diagram of the enrollment process for study subjects.

We categorized the potential factors to assess the ABI value in this study (Table 2). The subjects with an older age, male sex, a higher BMI, a higher diastolic brachial blood pressure, a lower heart rate, a higher total cholesterol level, higher triglycerides, a lower eGFR, a higher baPWV, a lower serum VCAM-1 level, and higher CRP level had a higher ABI value than the other corresponding groups. Furthermore, ABI values were significantly correlated with free T4 levels (correlation coefficient $[r]=-0.335, \mathrm{P}<0.001$; Fig. 2 ), but were not significantly correlated with CRP levels $(\mathrm{P}=0.813)$.

Because of the pathophysiological relationship between VCAM-1 and hyperthyroidism, we grouped all subjects into four groups: low VCAM-1 without hyperthyroidism $(n=142)$, high VCAM-1 without hyperthyroidism $(n=93)$, low VCAM-1 with hyperthyroidism $(n=15)$, and high VCAM-1 with hyperthyroidism $(n=66)$ according to the hyperthyroid status and the serum VCAM-1 median of $1055 \mathrm{ng} / \mathrm{mL}$. As shown in Fig. 3, there was a significant reduction in the ABI value in the patients with hyperthyroidism ( $\mathrm{P}$ value for trend $<0.001$ ). In addition to age and sex, we selected the confounding factors as those variables which significantly influenced both hyperthyroidism status (shown in Table 1) and the ABI value (shown in Table 2) for the multivariate regression analysis. A high VCAM-1 level with hyperthyroidism was an independent risk factor for a low ABI value after adjustments for age, BMI, heart rate, total cholesterol, triglycerides, and eGFR (regression coefficient $=-0.050$, 95\% CI between -0.080 and $-0.019 ; \mathrm{P}=0.001$, Table 3 ).

Longitudinal assessment of the subjects who had undergone antithyroid treatment. In the case group, all 32 recruited subjects completed assessments after treatment with antithyroid drugs for least 4 weeks. The median follow-up duration was 77 days (interquartile range between 57 and 123 days). The baseline characteristics of cases who participated in the follow-up were not significantly different from those of cases who did not participate in the follow-up. In the 32 subjects in the control group, the median follow-up duration was 87 days (interquartile range between 35 and 121 days). Despite being matched for age and sex, the subjects in the control group had a lower heart rate $(\mathrm{P}<0.001)$, a higher total cholesterol level $(\mathrm{P}<0.001)$, a higher HDL cholesterol level $(\mathrm{P}=0.024)$, a lower eGFR $(\mathrm{P}<0.001)$, a higher $\mathrm{ABI}$ value $(\mathrm{P}<0.001)$, and a lower serum VCAM-1 level $(\mathrm{P}<0.001)$ at baseline than the 32 subjects in the case group (Table 4$).$ 


\begin{tabular}{|l|l|l|r|}
\hline & Graves' disease $(\mathbf{n}=\mathbf{8 1})$ & Euthyroidism $(\mathbf{n}=\mathbf{2 3 5})$ & P \\
\hline Age $($ years $)$ & $37 \pm 12$ & $45 \pm 14$ & $<0.001$ \\
\hline Male, $\mathrm{n}(\%)$ & $15(18.5 \%)$ & $27(11.5 \%)$ & 0.156 \\
\hline Current smoker, n $(\%)$ & $22(27.2 \%)$ & $12(5.1 \%)$ & $<0.001$ \\
\hline BMI $\left(\mathrm{kg} / \mathrm{m}^{2}\right)$ & $21.7 \pm 2.7$ & $23.5 \pm 3.9$ & $<0.001$ \\
\hline Systolic BP $(\mathrm{mmHg})$ & $124 \pm 15$ & $120 \pm 15$ & 0.028 \\
\hline Diastolic BP $(\mathrm{mmHg})$ & $70 \pm 9$ & $71 \pm 10$ & 0.601 \\
\hline Heart rate $($ beats/min) & $89 \pm 16$ & $74 \pm 11$ & $<0.001$ \\
\hline Fasting glucose $(\mathrm{mmol} / \mathrm{L})$ & $5.2 \pm 1.6$ & $4.8 \pm 1.1$ & 0.007 \\
\hline Total cholesterol $(\mathrm{mmol} / \mathrm{L})$ & $3.7 \pm 0.8$ & $4.8 \pm 0.9$ & $<0.001$ \\
\hline HDL cholesterol $(\mathrm{mmol} / \mathrm{L})$ & $1.4 \pm 0.3$ & $1.5 \pm 0.4$ & $<0.001$ \\
\hline Triglycerides $(\mathrm{mmol} / \mathrm{L})$ & $1.2 \pm 0.7$ & $1.6 \pm 1.2$ & 0.008 \\
\hline eGFR $\left(\mathrm{mL} / \mathrm{min} / 1.73 \mathrm{~m}{ }^{2}\right)$ & $142.8 \pm 45.6$ & $95.0 \pm 18.4$ & $<0.001$ \\
\hline TSH $(\mu \mathrm{IU} / \mathrm{mL})$ & $0.015 \pm 0.043$ & $1.547 \pm 0.834$ & $<0.001$ \\
\hline Free T4 $(\mathrm{pg} / \mathrm{mL})$ & $37.1 \pm 14.2$ & $11.4 \pm 1.6$ & $<0.001$ \\
\hline ABI & $0.98 \pm 0.11$ & $1.06 \pm 0.10$ & $<0.001$ \\
\hline Categories of ABI, n $(\%)$ & & & $<0.001$ \\
\hline ABI $\leq 0.90$ & $21(25.9 \%)$ & $12(5.1 \%)$ & \\
\hline ABI between $0.91 \mathrm{and} 0.99$ & $23(28.4 \%)$ & $58(24.7 \%)$ & 0.784 \\
\hline ABI $\geq 1.00$ & $37(45.7 \%)$ & $165(70.2 \%)$ & \\
\hline baPWV & $1345 \pm 204$ & $1378 \pm 239$ & \\
\hline Ankle systolic BP $(\mathrm{mmHg})$ & $125 \pm 21$ & $131 \pm 22$ & \\
\hline VCAM-1 $(\mathrm{ng} / \mathrm{mL})$ & $1309 \pm 292$ & & \\
\hline C-reactive protein $(\mathrm{mg} / \mathrm{L})$ & $1.6 \pm 4.5$ & & \\
\hline
\end{tabular}

Table 1. Clinical characteristics of the subjects with Graves' disease and euthyroidism. $A B I$ ankle-brachial index, $b a P W V$ brachial-ankle pulse wave velocity, $B M I$ body mass index, $B P$ blood pressure, $e G F R$ estimated glomerular filtration rate, Free T4 free thyroxine, $H D L$ high-density lipoprotein, VCAM-1 vascular cell adhesion molecule-1, TSH thyroid-stimulating hormone.

After treatment with antithyroid drugs, free T4 significantly decreased $(-22.189 \mathrm{pg} / \mathrm{mL}, 95 \%$ CI between -27.347 and $-17.031 \mathrm{pg} / \mathrm{mL})$, but TSH did not significantly increase $(2.600 \mu \mathrm{IU} / \mathrm{mL}, 95 \%$ CI between -1.713 and $6.912 \mu \mathrm{IU} / \mathrm{mL}$ ). Significant increases in BMI, total cholesterol level, and HDL cholesterol level were observed, and significant decreases in systolic and diastolic brachial blood pressure and heart rate were also observed during the follow-up period. A significant increase in ABI values and a decrease in VCAM-1 levels were also observed (Table 5). The increase in ABI values was significantly correlated with a decrease in free T4 levels $(r=-0.406$, $\mathrm{P}=0.021$ ). In the control group, only the eGFR significantly increased and the VCAM-1 level significantly decreased during the observation follow-up period. The association between changes in free T4 levels and ABI values was not significant $(r=0.074, \mathrm{P}=0.689)$ in the control group.

Using multivariate linear regression, treatment with antithyroid drugs was an independent factor associated with an increased percentage change in the $\mathrm{ABI}$ value (regression coefficient $=-0.003,95 \%$ CI between -0.005 and $-0.001, \mathrm{P}=0.001$ ) during the follow-up of the study after adjustment for age, sex, change in BMI, and change in heart rate (Table 6).

\section{Discussion}

Our main findings are that a lower ABI was observed in patients with hyperthyroidism and high circulating VCAM-1 levels. After treatment with antithyroid drugs, ABI values were significantly increased, and the increase in the ABI values was correlated with a reduction in the circulating free T4 level. A lower ABI was associated with a higher mortality risk in subjects with an $A B I$ value $<1.1^{21,26}$, and an $A B I$ value $<1.0$ should be considered to indicate a borderline abnormal ABI, as there was an association with increased CV risk even when the ABI value was $>0.9^{27}$. In the present study, Graves' disease was related to a significant decrease in ankle systolic blood pressure, resulting in a low $\mathrm{ABI}$, as a predictor of $\mathrm{CV}$ disease.

Patients with Graves' disease had a higher mean VCAM-1 level than those with normal thyroid function. It has been reported that a high circulating VCAM-1 level was detected in patients with Graves' disease, and the level was positively correlated with the free T4 levels ${ }^{28}$. The increased VCAM-1 level resulted from enhanced expression in the endothelium due to lymphocyte infiltration in the thyroid gland ${ }^{12,29,30}$. However, VCAM-1 released in the blood might induce chronic inflammation and endothelial dysfunction in peripheral arteries ${ }^{13}$. De Ciuceis et al. ${ }^{31}$ reported an increased level of VCAM-1 and a decreased number of endothelial progenitor cells in peripheral blood during hyperthyroid status in patients with Graves' disease. Endothelial dysfunction was also associated with an increase in asymmetric dimethylarginine in patients with Graves' disease ${ }^{32,33}$.

In the present study, only the VCAM-1 level, but not the CRP level, was significantly increased in patients with Graves' disease. In line with our finding, Burggraaf et al. ${ }^{34}$ reported that the CRP level was not significantly 


\begin{tabular}{|c|c|c|c|}
\hline & $\mathbf{n}$ & ABI & $\mathbf{P}$ \\
\hline Age $^{*}$ & & & $<0.001$ \\
\hline$<41.4$ years & 158 & $0.99 \pm 0.10$ & \\
\hline$\geq 41.4$ years & 158 & $1.08 \pm 0.09$ & \\
\hline Sex & & & 0.002 \\
\hline Female & 274 & $1.03 \pm 0.10$ & \\
\hline Male & 42 & $1.08 \pm 0.13$ & \\
\hline Current smoking & & & 0.101 \\
\hline No & 282 & $1.04 \pm 0.10$ & \\
\hline Yes & 34 & $1.01 \pm 0.13$ & \\
\hline BMI $^{*}$ & & & 0.002 \\
\hline$<22.5 \mathrm{~kg} / \mathrm{m}^{2}$ & 158 & $1.02 \pm 0.10$ & \\
\hline$\geq 22.5 \mathrm{~kg} / \mathrm{m}^{2}$ & 158 & $1.05 \pm 0.10$ & \\
\hline Systolic BP & & & 0.701 \\
\hline$<120 \mathrm{mmHg}$ & 164 & $1.03 \pm 0.10$ & \\
\hline$\geq 120 \mathrm{mmHg}$ & 152 & $1.04 \pm 0.11$ & \\
\hline Diastolic BP & & & 0.001 \\
\hline$<70 \mathrm{mmHg}$ & 150 & $1.02 \pm 0.11$ & \\
\hline$\geq 70 \mathrm{mmHg}$ & 166 & $1.05 \pm 0.10$ & \\
\hline Heart rate ${ }^{*}$ & & & $<0.001$ \\
\hline$<76$ beats $/ \mathrm{min}$ & 156 & $1.07 \pm 0.09$ & \\
\hline$\geq 76$ beats $/ \mathrm{min}$ & 160 & $1.00 \pm 0.11$ & \\
\hline Fasting glucose & & & 0.933 \\
\hline$<5.56 \mathrm{mmol} / \mathrm{L}$ & 252 & $1.04 \pm 0.11$ & \\
\hline$\geq 5.56 \mathrm{mmol} / \mathrm{L}$ & 64 & $1.04 \pm 0.11$ & \\
\hline Total cholesterol & & & 0.017 \\
\hline$<5.18 \mathrm{mmol} / \mathrm{L}$ & 231 & $1.03 \pm 0.11$ & \\
\hline$\geq 5.18 \mathrm{mmol} / \mathrm{L}$ & 85 & $1.06 \pm 0.09$ & \\
\hline Low HDL cholesterol & & & 0.051 \\
\hline No & 246 & $1.04 \pm 0.10$ & \\
\hline Yes & 70 & $1.01 \pm 0.11$ & \\
\hline Triglycerides & & & 0.006 \\
\hline$<1.70 \mathrm{mmol} / \mathrm{L}$ & 235 & $1.03 \pm 0.11$ & \\
\hline$\geq 1.70 \mathrm{mmol} / \mathrm{L}$ & 81 & $1.06 \pm 0.10$ & \\
\hline eGFR $^{\star}$ & & & $<0.001$ \\
\hline$<98.9 \mathrm{~mL} / \mathrm{min} / 1.73 \mathrm{~m}^{2}$ & 158 & $1.07 \pm 0.10$ & \\
\hline$\geq 98.9 \mathrm{~mL} / \mathrm{min} / 1.73 \mathrm{~m}^{2}$ & 158 & $1.01 \pm 0.11$ & \\
\hline baPWV & & & $<0.001$ \\
\hline$<1400 \mathrm{~cm} / \mathrm{s}$ & 198 & $1.02 \pm 0.11$ & \\
\hline$\geq 1400 \mathrm{~cm} / \mathrm{s}$ & 118 & $1.07 \pm 0.10$ & \\
\hline VCAM-1* & & & 0.010 \\
\hline$<1055 \mathrm{ng} / \mathrm{mL}$ & 157 & $1.05 \pm 0.10$ & \\
\hline$\geq 1055 \mathrm{ng} / \mathrm{mL}$ & 159 & $1.02 \pm 0.11$ & \\
\hline C-reactive protein ${ }^{*}$ & & & 0.005 \\
\hline$<0.6 \mathrm{mg} / \mathrm{L}$ & 159 & $1.02 \pm 0.11$ & \\
\hline$\geq 0.6 \mathrm{mg} / \mathrm{L}$ & 157 & $1.05 \pm 0.10$ & \\
\hline
\end{tabular}

Table 2. ABI values according to associated risk factors. $A B I$ ankle-brachial index, $b a P W V$ brachial-ankle pulse wave velocity, $B M I$ body mass index, $B P$ blood pressure, $e G F R$ estimated glomerular filtration rate, $H D L$ high-density lipoprotein, VCAM-1 vascular cell adhesion molecule-1, TSH thyroid-stimulating hormone. ${ }^{*}$ Cutoff value based on the median.

associated with thyroid function. Furthermore, the VCAM-1 level is reported to be strongly associated with $\mathrm{PAD}^{24}$. In the present study, high circulating VCAM-1 levels had a synergistic effect with hyperthyroidism on low ABI values. Therefore, VCAM-1 might be a mediator in the relationship between hyperthyroidism and PAD.

Antithyroid drugs have been the most popular therapy used to treat hyperthyroid status ${ }^{35,36}$. In the present study, the ABI values increased after treatment, with reductions in both free T4 levels and VCAM-1 levels. In line with our data, antithyroid drugs have been reported to reduce circulating VCAM-1 levels ${ }^{28}$, and improve 


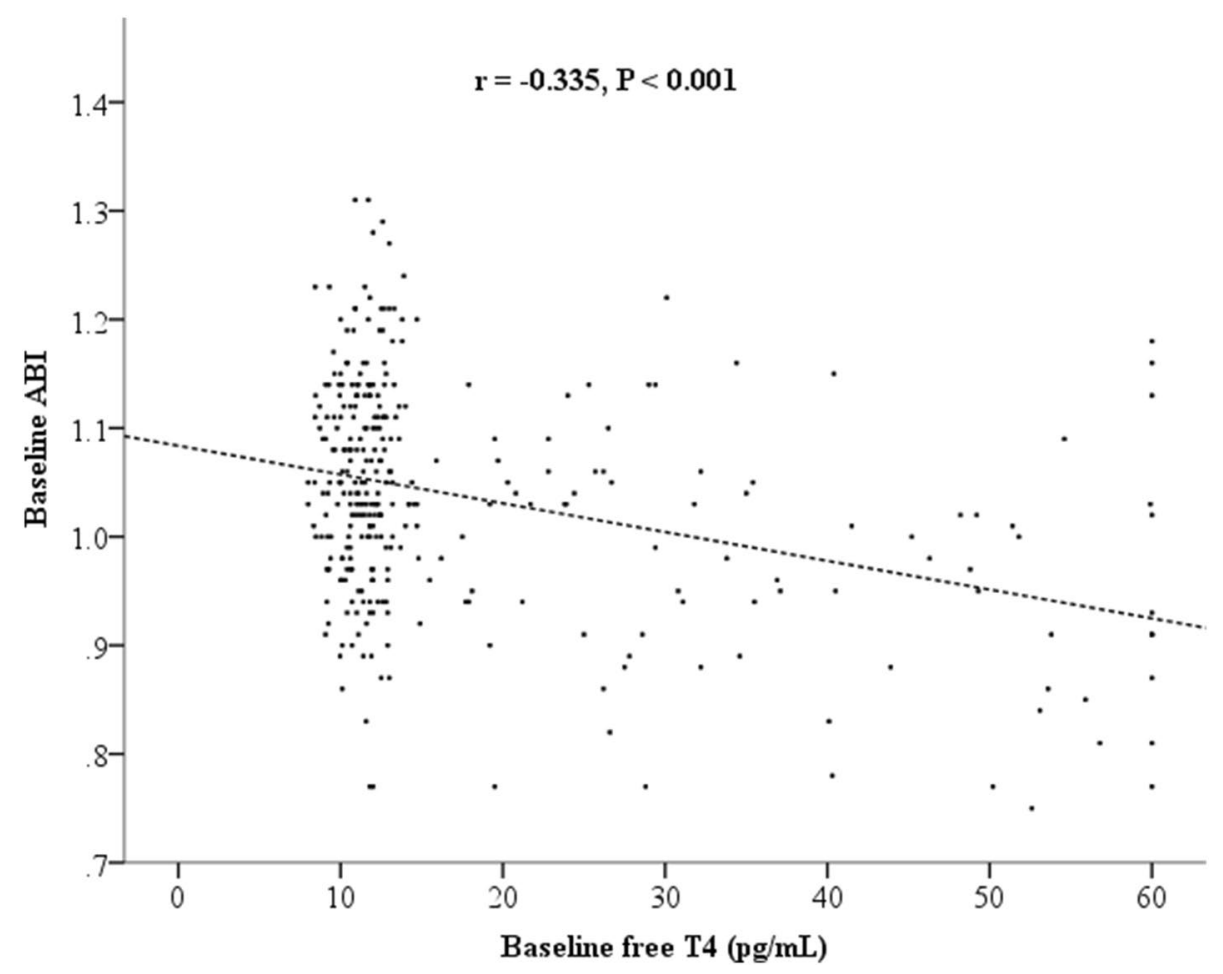

Figure 2. The correlation between the ABI values and free thyroxine (T4) levels at baseline ( $r=$ correlation coefficient).

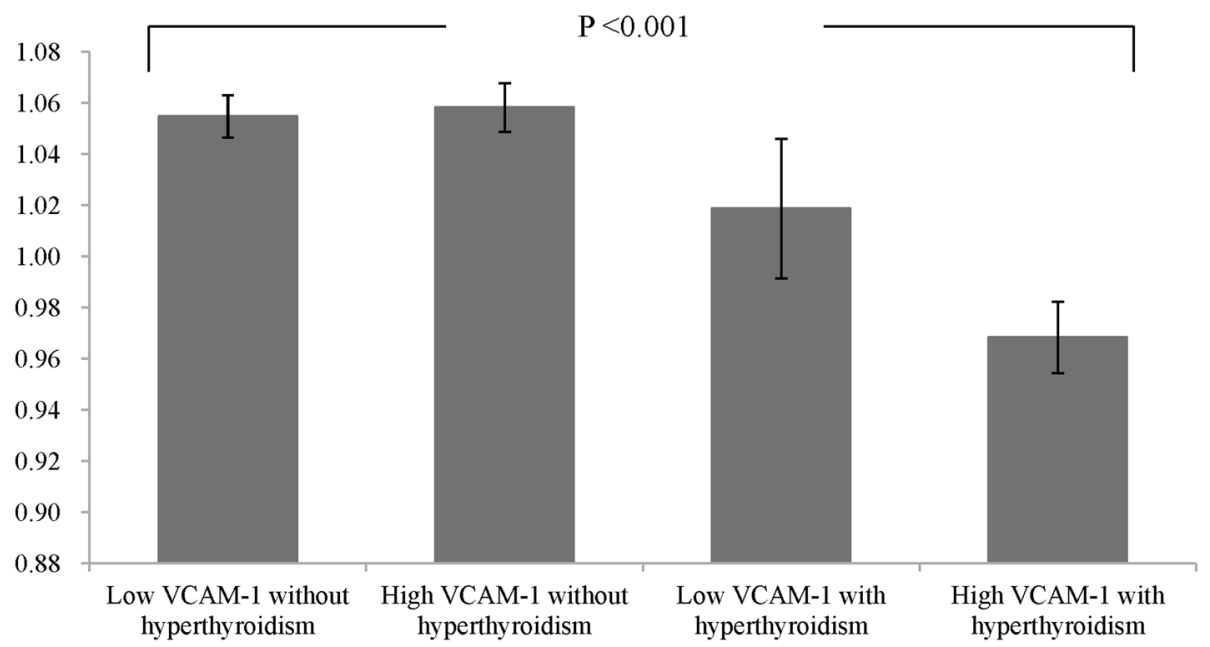

Figure 3. Ankle-brachial index (ABI) values are presented in the following groups: low vascular cell adhesion molecule-1 (VCAM-1) without hyperthyroidism, high VCAM-1 without hyperthyroidism, low VCAM-1 with hyperthyroidism, and high VCAM-1 with hyperthyroidism ( $\mathrm{P}$ value for trend $<0.001$ ). Patients were grouped according to hyperthyroid status and median serum VCAM-1 level (1055 ng/mL).

endothelial function ${ }^{14}$. Furthermore, an increased number of endothelial progenitor cells and decreased biomarkers of platelet activity were also reported after hyperthyroidism treatment ${ }^{31,37}$.

To the best of our knowledge, the present study is the first report of the relationship between the ABI and Graves' disease. However, there are some limitations in the present study. First, we did not examine the mechanism or causal relationship between hyperthyroidism and PAD. Second, Graves' disease was newly diagnosed in all patients with hyperthyroidism. However, we did not know the definitive time when hyperthyroidism occurred before diagnosis due to the diversity of symptoms. Third, our findings may not be applicable to patients with diabetes who were excluded due to a potential noncompressible artery at the ankle ${ }^{38,39}$. Fourth, we assessed only a reversible $\mathrm{ABI}$ reduction after treatment with antithyroid drugs but not long-term outcomes, such as 


\begin{tabular}{|c|c|c|c|c|c|c|c|c|c|}
\hline & \multicolumn{3}{|l|}{ Crude } & \multicolumn{3}{|c|}{ Model 1} & \multicolumn{3}{|c|}{ Model 2} \\
\hline & B & $95 \% \mathrm{CI}$ & $\mathbf{P}$ & B & 95\% CI & $\mathbf{P}$ & B & $95 \% \mathrm{CI}$ & $\mathbf{P}$ \\
\hline $\begin{array}{l}\text { Low VCAM-1 } \\
\text { without hyperthy- } \\
\text { roidism }\end{array}$ & Ref. & & & Ref. & & & Ref. & & \\
\hline \begin{tabular}{|l|} 
High VCAM-1 \\
without hyperthy- \\
roidism
\end{tabular} & 0.003 & $(-0.023,0.030)$ & 0.793 & -0.010 & $(-0.035,0.014)$ & 0.399 & -0.009 & $(-0.033,0.015)$ & 0.450 \\
\hline $\begin{array}{l}\text { Low VCAM-1 with } \\
\text { hyperthyroidism }\end{array}$ & -0.036 & $(-0.089,0.017)$ & 0.184 & -0.031 & $(-0.080,0.018)$ & 0.212 & -0.009 & $(-0.058,0.041)$ & 0.728 \\
\hline $\begin{array}{l}\text { High VCAM-1 with } \\
\text { hyperthyroidism }\end{array}$ & -0.086 & $(-0.116,-0.057)$ & $<0.001$ & -0.078 & $(-0.105,-0.051)$ & $<0.001$ & -0.050 & $(-0.080,-0.019)$ & 0.001 \\
\hline Age $\geq 41.4$ years & & & & 0.071 & $(0.050,0.092)$ & $<0.001$ & 0.065 & $(0.043,0.087)$ & $<0.001$ \\
\hline Male & & & & 0.052 & $(0.022,0.082)$ & $<0.001$ & 0.046 & $(0.016,0.077)$ & 0.003 \\
\hline $\mathrm{BMI} \geq 22.5 \mathrm{~kg} / \mathrm{m}^{2}$ & & & & & & & 0.008 & $(-0.013,0.029)$ & 0.450 \\
\hline $\begin{array}{l}\text { Hear rate } \geq 76 \text { beats } / \\
\text { min }\end{array}$ & & & & & & & -0.047 & $(-0.069,-0.026)$ & $<0.001$ \\
\hline $\begin{array}{l}\text { Total choles- } \\
\text { terol } \geq 5.18 \mathrm{mmol} / \mathrm{L}\end{array}$ & & & & & & & -0.006 & $(-0.030,0.018)$ & 0.64 \\
\hline $\begin{array}{l}\text { Triglycer- } \\
\text { ides } \geq 1.70 \mathrm{mmol} / \mathrm{L}\end{array}$ & & & & & & & 0.012 & $(-0.012,0.036)$ & 0.320 \\
\hline $\begin{array}{l}\mathrm{eGFR} \geq 98.9 \mathrm{~mL} / \\
\mathrm{min} / 1.73 \mathrm{~m}^{2}\end{array}$ & & & & & & & -0.014 & $(-0.037,0.009)$ & 0.239 \\
\hline
\end{tabular}

Table 3. Multivariate regression analysis showing the factors associated with the ankle-brachial index (ABI) values. $B$ regression coefficient, Model 1 adjusted for age and sex, Model 2 adjusted for age, sex, and the risk factors selected from Tables 1 and 2, ABI ankle-brachial index, BMI body mass index, $C I$ confidence interval, eGFR estimated glomerular filtration rate, VCAM-1 vascular cell adhesion molecule-1.

\begin{tabular}{|c|c|c|c|c|c|}
\hline & \multicolumn{2}{|c|}{$\begin{array}{l}\text { Case without follow } \\
\text { up }(n=49)\end{array}$} & \multirow{2}{*}{$\begin{array}{l}\text { Case with follow up }(n=32) \\
\text { Mean } \pm \text { SD }\end{array}$} & \multicolumn{2}{|c|}{$\begin{array}{l}\text { Controls with follow up } \\
(\mathrm{n}=32)\end{array}$} \\
\hline & Mean \pm SD & $\mathbf{P}^{*}$ & & Mean \pm SD & $\mathbf{P}^{\#}$ \\
\hline Age (years) & $38 \pm 11$ & 0.360 & $36 \pm 13$ & $41 \pm 11$ & 0.074 \\
\hline Male, n (\%) & $12(24.5 \%)$ & 0.156 & $3(9.4 \%)$ & $3(9.4 \%)$ & 0.999 \\
\hline BMI $\left(\mathrm{kg} / \mathrm{m}^{2}\right)$ & $21.6 \pm 2.6$ & 0.711 & $21.8 \pm 2.8$ & $23.0 \pm 3.9$ & 0.154 \\
\hline Systolic BP (mmHg) & $125 \pm 15$ & 0.811 & $124 \pm 16$ & $117 \pm 13$ & 0.081 \\
\hline Diastolic BP (mmHg) & $71 \pm 10$ & 0.194 & $69 \pm 9$ & $70 \pm 10$ & 0.500 \\
\hline Heart rate (beat/min) & $90 \pm 16$ & 0.499 & $88 \pm 16$ & $73 \pm 12$ & $<0.001$ \\
\hline Fasting glucose $(\mathrm{mmol} / \mathrm{L})$ & $5.3 \pm 1.9$ & 0.267 & $4.9 \pm 1.0$ & $4.6 \pm 0.9$ & 0.174 \\
\hline Total cholesterol (mmol/L) & $3.8 \pm 0.8$ & 0.053 & $3.5 \pm 0.8$ & $4.7 \pm 0.8$ & $<0.001$ \\
\hline HDL cholesterol (mmol/L) & $1.4 \pm 0.3$ & 0.305 & $1.3 \pm 0.3$ & $1.5 \pm 0.3$ & 0.024 \\
\hline Triglycerides (mmol/L) & $1.3 \pm 0.7$ & 0.085 & $1.0 \pm 0.7$ & $1.3 \pm 1.2$ & 0.234 \\
\hline eGFR $\left(\mathrm{mL} / \mathrm{min} / 1.73 \mathrm{~m}^{2}\right)$ & $137 \pm 44$ & 0.185 & $151 \pm 48$ & $91 \pm 14$ & $<0.001$ \\
\hline $\mathrm{TSH}(\mu \mathrm{IU} / \mathrm{mL})$ & $0.016 \pm 0.051$ & 0.756 & $0.013 \pm 0.030$ & $1.383 \pm 0.861$ & $<0.001$ \\
\hline Free T4 (pg/mL) & $37.6 \pm 13.9$ & 0.672 & $36.2 \pm 14.9$ & $11.7 \pm 1.5$ & $<0.001$ \\
\hline $\mathrm{ABI}$ & $0.99 \pm 0.12$ & 0.156 & $0.96 \pm 0.10$ & $1.05 \pm 0.10$ & $<0.001$ \\
\hline $\mathrm{baPWV}(\mathrm{cm} / \mathrm{s})$ & $1343 \pm 177$ & 0.907 & $1348 \pm 242$ & $1319 \pm 157$ & 0.565 \\
\hline Ankle systolic BP (mmHg) & $124 \pm 19$ & 0.340 & $120 \pm 22$ & $125 \pm 18$ & 0.352 \\
\hline VCAM-1 (ng/mL) & $1305 \pm 332$ & 0.902 & $1314 \pm 221$ & $982 \pm 168$ & $<0.001$ \\
\hline C-reactive protein $(\mathrm{mg} / \mathrm{L})$ & $1.2 \pm 2.0$ & 0.248 & $2.4 \pm 6.8$ & $1.0 \pm 1.8$ & 0.281 \\
\hline
\end{tabular}

Table 4. Baseline clinical characteristics of the subjects with and without follow-up in the Graves' disease group and the control group. The control group included baseline euthryoid subjects matched for age and sex to cases with follow-up. $A B I$ ankle-brachial index, $b a P W V$ brachial-ankle pulse wave velocity, $B M I$ body mass index, $B P$ blood pressure, $e G F R$ estimated glomerular filtration rate, Free T4 free thyroxine, $H D L$ high-density lipoprotein, VCAM-1 vascular cell adhesion molecule-1, TSH thyroid-stimulating hormone. ${ }^{*} \mathrm{P}$ : case without follow-up vs. case with follow-up. ${ }^{\#} \mathrm{P}$ : case with follow-up vs. control with follow-up. 


\begin{tabular}{|c|c|c|c|c|c|}
\hline & \multicolumn{2}{|c|}{ Cases $(n=32)$} & \multicolumn{2}{|c|}{ Controls $(n=32)$} & \multirow[b]{2}{*}{$\mathbf{P}^{*}$} \\
\hline & Mean & $95 \% \mathrm{CI}$ & Mean & $95 \% \mathrm{CI}$ & \\
\hline BMI $\left(\mathrm{kg} / \mathrm{m}^{2}\right)$ & 0.548 & $(0.134,0.963)$ & 0.130 & $(-0.125,0.385)$ & 0.084 \\
\hline Systolic BP (mmHg) & -7.594 & $(-11.616,-3.572)$ & 1.438 & $(-2.104,4.979)$ & 0.001 \\
\hline Diastolic BP (mmHg) & -3.063 & $(-5.678,-0.447)$ & 1.094 & $(-1.846,4.033)$ & 0.035 \\
\hline Heart rate (beats/min) & -10.906 & $(-17.582,-4.230)$ & -1.438 & $(-4.408,1.533)$ & 0.010 \\
\hline Fasting glucose $(\mathrm{mmol} / \mathrm{L})$ & -0.347 & $(-0.800,0.106)$ & -0.052 & $(-0.536,0.431)$ & 0.367 \\
\hline Total cholesterol $(\mathrm{mmol} / \mathrm{L})$ & 0.908 & $(0.651,1.166)$ & -0.049 & $(-0.255,0.156)$ & $<0.001$ \\
\hline HDL cholesterol $(\mathrm{mmol} / \mathrm{L})$ & 0.265 & $(0.169,0.360)$ & 0.019 & $(-0.043,0.082)$ & $<0.001$ \\
\hline Triglycerides $(\mathrm{mmol} / \mathrm{L})$ & 0.252 & $(-0.117,0.622)$ & -0.154 & $(-0.513,0.205)$ & 0.113 \\
\hline eGFR $\left(\mathrm{mL} / \mathrm{min} / 1.73 \mathrm{~m}^{2}\right)$ & -15.963 & $(-33.059,1.133)$ & 8.229 & $(4.009,12.448)$ & 0.007 \\
\hline TSH $(\mu \mathrm{IU} / \mathrm{mL})$ & 2.600 & $(-1.713,6.912)$ & 0.195 & $(-0.267,0.656)$ & 0.262 \\
\hline Free $\mathrm{T} 4(\mathrm{pg} / \mathrm{mL})$ & -22.189 & $(-27.347,-17.031)$ & 0.319 & $(-0.046,0.684)$ & $<0.001$ \\
\hline ABI & 0.090 & $(0.044,0.136)$ & 0.009 & $(-0.025,0.042)$ & 0.005 \\
\hline $\mathrm{baPWV}(\mathrm{cm} / \mathrm{s})$ & -48.84 & $(-110.69,13.00)$ & -13.34 & $(-57.46,30.78)$ & 0.344 \\
\hline VCAM-1 (ng/mL) & -301.1 & $(-384.0,-218.3)$ & -101.1 & $(-147.1,-55.0)$ & $<0.001$ \\
\hline C-reactive protein $(\mathrm{mg} / \mathrm{L})$ & -0.132 & $(-0.368,0.104)$ & 0.023 & $(-0.011,0.058)$ & 0.183 \\
\hline
\end{tabular}

Table 5. Differences from baseline values after follow-up. ${ }^{\star}$ Denotes $P$ values for differences between case and control groups. $A B I$ ankle-brachial index, $b a P W V$ brachial-ankle pulse wave velocity, $B M I$ body mass index, $B P$ blood pressure, $e G F R$ estimated glomerular filtration rate, Free T4 free thyroxine, $H D L$ high-density lipoprotein, TSH thyroid-stimulating hormone, VCAM-1 vascular cell adhesion molecule-1.

\begin{tabular}{|l|l|l|r|}
\hline & B & $\mathbf{9 5 \%}$ CI & P \\
\hline Crude & -0.004 & $(-0.006,-0.002)$ & $<0.001$ \\
\hline Model 1 & -0.004 & $(-0.006,-0.002)$ & $<0.001$ \\
\hline Model 2 & -0.003 & $(-0.005,-0.001)$ & 0.001 \\
\hline
\end{tabular}

Table 6. The effect of changes in free thyroxine levels on the percentage change in the ankle-brachial index. $B$ regression coefficient, CI confidence interval, Model 1 adjusted for age and sex, Model 2 adjusted for age, sex, change in body mass index, and change in heart rate.

lower-extremity amputation. Finally, we did not compare the effects of different Graves' disease treatments on the ABI. It was reported that additional radioiodine therapy was associated with low long-term mortality ${ }^{11}$. Further large-scale studies with controlled treatment are needed to investigate the relationship between hyperthyroidism and PAD.

In conclusion, a higher free T4 level is associated with a lower ABI value in patients with untreated Graves' disease. A high circulating VCAM-1 level had a superimposing effect on the decrease in the ABI value during hyperthyroid status. After treatment with antithyroid drugs, an increase in ABI values accompanied by reductions in free T4 and VCAM-1 levels was observed.

Received: 26 March 2020; Accepted: 28 September 2020

Published online: 13 October 2020

\section{References}

1. Garmendia Madariaga, A., Santos Palacios, S., Guillen-Grima, F. \& Galofre, J. C. The incidence and prevalence of thyroid dysfunction in Europe: a meta-analysis. J. Clin. Endocrinol. Metab. 99, 923-931 (2014).

2. Hollowell, J. G. et al. Serum TSH, T(4), and thyroid antibodies in the United States population (1988 to 1994): National Health and Nutrition Examination Survey (NHANES III). J. Clin. Endocrinol. Metab. 87, 489-499 (2002).

3. De Leo, S., Lee, S. Y. \& Braverman, L. E. Hyperthyroidism. Lancet 388, 906-918 (2016).

4. Weetman, A. P. Grave's disease 1835-2002. Horm. Res. 59(Suppl 1), 114-118 (2003).

5. Wemeau, J. L., Klein, M., Sadoul, J. L., Briet, C. \& Velayoudom-Cephise, F. L. Graves' disease: introduction, epidemiology, endogenous and environmental pathogenic factors. Ann. Endocrinol. (Paris) 79, 599-607 (2018).

6. Jabbar, A. et al. Thyroid hormones and cardiovascular disease. Nat. Rev. Cardiol. 14, 39-55 (2017).

7. Biondi, B. Mechanisms in endocrinology: heart failure and thyroid dysfunction. Eur. J. Endocrinol. 167, 609-618 (2012).

8. Siu, C. W., Yeung, C. Y., Lau, C. P., Kung, A. W. \& Tse, H. F. Incidence, clinical characteristics and outcome of congestive heart failure as the initial presentation in patients with primary hyperthyroidism. Heart 93, 483-487 (2007).

9. Dekkers, O. M. et al. Acute cardiovascular events and all-cause mortality in patients with hyperthyroidism: a population-based cohort study. Eur. J. Endocrinol. 176, 1-9 (2017).

10. Brandt, F. et al. Graves' disease and toxic nodular goiter are both associated with increased mortality but differ with respect to the cause of death: a Danish population-based register study. Thyroid 23, 408-413 (2013). 
11. Okosieme, O. E. et al. Primary therapy of Graves' disease and cardiovascular morbidity and mortality: a linked-record cohort study. Lancet Diabetes Endocrinol. 7, 278-287 (2019).

12. Marazuela, M. et al. Adhesion molecules from the LFA-1/ICAM-1,3 and VLA-4/VCAM-1 pathways on T lymphocytes and vascular endothelium in Graves' and Hashimoto's thyroid glands. Eur. J. Immunol. 24, 2483-2490 (1994).

13. Poplawska-Kita, A. et al. The changes in the endothelial function and haemostatic and inflammatory parameters in subclinical and overt hyperthyroidism. Int. J. Endocrinol. 2013, 981638 (2013).

14. Hosseini, S. M., Bakhtyari, E. K., Heshmat-Ghahdarijani, K. \& Khalili, N. Evaluation of endothelial function in exogenous subclinical hyperthyroidism and the effect of treatment. Adv. Biomed. Res. 5, 173 (2016).

15. Diehm, C. et al. Mortality and vascular morbidity in older adults with asymptomatic versus symptomatic peripheral artery disease. Circulation 120, 2053-2061 (2009).

16. Pande, R. L., Perlstein, T. S., Beckman, J. A. \& Creager, M. A. Secondary prevention and mortality in peripheral artery disease: National Health and Nutrition Examination Study, 1999 to 2004. Circulation 124, 17-23 (2011).

17. Hiatt, W. R. Medical treatment of peripheral arterial disease and claudication. N. Engl. J. Med. 344, 1608-1621 (2001).

18. Alves-Cabratosa, L. et al. Role of low ankle-brachial index in cardiovascular and mortality risk compared with major risk conditions. J. Clin. Med. 8, 870 (2019).

19. Heald, C. L., Fowkes, F. G., Murray, G. D., Price, J. F. \& Ankle Brachial Index Collaboration. Risk of mortality and cardiovascular disease associated with the ankle-brachial index: systematic review. Atherosclerosis 189, 61-69 (2006).

20. Gerhard-Herman, M. D. et al. 2016 AHA/ACC guideline on the management of patients with lower extremity peripheral artery disease: a report of the American College of Cardiology/American Heart Association Task Force on Clinical Practice Guidelines. Circulation 135, e726-e779 (2017).

21. Resnick, H. E. et al. Relationship of high and low ankle brachial index to all-cause and cardiovascular disease mortality: the Strong Heart Study. Circulation 109, 733-739 (2004).

22. Cai, Y. et al. Thyroid hormone affects both endothelial and vascular smooth muscle cells in rat arteries. Eur. J. Pharmacol. 747, 18-28 (2015).

23. Silvestro, A., Brevetti, G., Schiano, V., Scopacasa, F. \& Chiariello, M. Adhesion molecules and cardiovascular risk in peripheral arterial disease. Soluble vascular cell adhesion molecule-1 improves risk stratification. Thromb. Haemost. 93, 559-563 (2005)

24. Edlinger, C. et al. Disease-specific characteristics of vascular cell adhesion molecule-1 levels in patients with peripheral artery disease. Heart Vessels. 34, 976-983 (2019).

25. Inker, L. A. et al. KDOQI US commentary on the 2012 KDIGO clinical practice guideline for the evaluation and management of CKD. Am. J. Kidney Dis. 63, 713-735 (2014).

26. McDermott, M. M. et al. Associations of borderline and low normal ankle-brachial index values with functional decline at 5-year follow-up: the WALCS (Walking and Leg Circulation Study). J. Am. Coll. Cardiol. 53, 1056-1062 (2009).

27. Writing Committee Members et al. AHA/ACC guideline on the management of patients with lower extremity peripheral artery disease: executive summary. Vasc. Med. 2017(22), NP1-NP43 (2016).

28. Wenisch, C. et al. Soluble endothelium-associated adhesion molecules in patients with Graves' disease. Clin. Exp. Immunol. 98, 240-244 (1994).

29. Nakashima, M. et al. The expression of adhesion molecules in thyroid glands from patients with Graves' disease. Thyroid 4, 19-25 (1994).

30. Jungheim, K., Caspar, G., Usadel, K. H. \& Schumm-Draeger, P. M. Expression of intracellular adhesion molecule-1 and vascular cell adhesion molecule-1 and homing factor CD44 after engraftment of Graves' lymphocytes in xenotransplanted human thyroid tissue in athymic nude mice. Thyroid 11, 831-837 (2001).

31. De Ciuceis, C. et al. Decreased number of circulating endothelial progenitor cells in patients with Graves' hyperthyroidism. J. Endocrinol. Investig. 34, 335-339 (2011).

32. Arikan, E., Karadag, C. H. \& Guldiken, S. Asymmetric dimethylarginine levels in thyroid diseases. J. Endocrinol. Investig. 30, 186-191 (2007).

33. Gu, L. Q. et al. Relationships between serum levels of thyroid hormones and serum concentrations of asymmetric dimethylarginine (ADMA) and N-terminal-pro-B-type natriuretic peptide (NT-proBNP) in patients with Graves' disease. Endocrine 39, 266-271 (2011).

34. Burggraaf, J. et al. Endothelial function in patients with hyperthyroidism before and after treatment with propranolol and thiamazol. Thyroid 11, 153-160 (2001).

35. Brito JP, Payne S, Singh-Ospina N, Rodriguez-Gutierrez R, Maraka S, Sangaralingham L, et al. Patterns of use, efficacy and safety of treatment options for patients with Graves' disease: A Nationwide Population-Based Study. Thyroid. 2020 (online ahead of print).

36. Ross, D. S. et al. 2016 American Thyroid Association guidelines for diagnosis and management of hyperthyroidism and other causes of thyrotoxicosis. Thyroid 26, 1343-1421 (2016).

37. Erem, C. et al. Signal peptide-CUB-EGF domain-containing protein 1 (SCUBE1) levels in patients with overt and subclinical hyperthyroidism: effects of treatment. Clin. Endocrinol. (Oxf) 84, 919-924 (2016).

38. Young, M. J., Adams, J. E., Anderson, G. F., Boulton, A. J. \& Cavanagh, P. R. Medial arterial calcification in the feet of diabetic patients and matched non-diabetic control subjects. Diabetologia 36, 615-621 (1993).

39. Rooke, T. W. et al. 2011 ACCF/AHA focused update of the guideline for the management of patients with peripheral artery disease (updating the 2005 guideline): a report of the American College of Cardiology Foundation/American Heart Association Task Force on Practice Guidelines: developed in collaboration with the Society for Cardiovascular Angiography and Interventions, Society of Interventional Radiology, Society for Vascular Medicine, and Society for Vascular Surgery. J. Vasc. Surg. 12, e32-e58 (2011).

\section{Acknowledgements}

Statistical analysis was performed by the Biostatistics Task Force of Taichung Veterans General Hospital, Taichung, Taiwan.

\section{Author contributions}

Y.L. participated in the data collection and writing of the manuscript. I.L. contributed to the study design, data collection, interpretation of the data, and revision of the manuscript.

\section{Funding}

This work was supported by a grant from Taichung Veterans General Hospital, Taichung, Taiwan (grant number TCVGH-1093503C) and the Ministry of Science and Technology, Taiwan (grant number MOST 109-2314-B-075A-004). The funders had no role in the decision to submit the manuscript for publication. 


\section{Competing interests}

The authors declare no competing interests.

\section{Additional information}

Correspondence and requests for materials should be addressed to I.-T.L.

Reprints and permissions information is available at www.nature.com/reprints.

Publisher's note Springer Nature remains neutral with regard to jurisdictional claims in published maps and institutional affiliations.

(c) (1) Open Access This article is licensed under a Creative Commons Attribution 4.0 International License, which permits use, sharing, adaptation, distribution and reproduction in any medium or format, as long as you give appropriate credit to the original author(s) and the source, provide a link to the Creative Commons licence, and indicate if changes were made. The images or other third party material in this article are included in the article's Creative Commons licence, unless indicated otherwise in a credit line to the material. If material is not included in the article's Creative Commons licence and your intended use is not permitted by statutory regulation or exceeds the permitted use, you will need to obtain permission directly from the copyright holder. To view a copy of this licence, visit http://creativecommons.org/licenses/by/4.0/.

(c) The Author(s) 2020 